DOI: https://doi.org/10.47405/mjssh.v6i10.1104

\begin{tabular}{|c|c|}
\hline 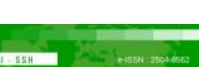 & Malaysian Journal of Social Sciences and Humanities (MJSSH) \\
\hline Malaysian Journal of & Volume 6, Issue 10, October 2021 \\
\hline (MJ-SSH) & e-ISSN : 2504-8562 \\
\hline & $\begin{array}{l}\text { Journal home page: } \\
\text { www.msocialsciences.com }\end{array}$ \\
\hline
\end{tabular}

\title{
Ciri-Ciri Kesesuaian Tajuk Komunikasi dalam Pembangunan Modul Pengajaran Bahasa Arab: Suatu Analisis Laras Bahasa Komunikatif
}

\author{
Ibrahim Abdullah ${ }^{1}$ \\ 1Jabatan Bahasa Asia dan Eropah, Akademi Pengajian Bahasa, \\ Universiti Teknologi MARA Shah Alam, Malaysia \\ Correspondence: Ibrahim Abdullah (ibrahim970@uitm.edu.my)
}

\begin{abstract}
Abstrak
Laras bahasa merupakan salah satu daripada cabang sosiolinguistik. Pemilihan laras bahasa komunikatif yang sesuai akan menjadikan modul pengajaran bahasa lebih bermakna. Kajian ini bertujuan untuk mengetahui ciri-ciri tajuk komunikatif dan kesesuaian tajuk berdasarkan pendekatan komunikatif. Pendekatan kajian adalah menggunakan temu bual pakar sebagai kaedah utama dan disokong dengan kaedah pemerhatian bagi memperoleh data kajian. Sampel temu bual terdiri daripada 8 orang pensyarah pakar. Data dikodkan, dianalisis secara tematik dan dihuraikan secara deskriptif. Tema-tema yang dihasilkan adalah berdasarkan pengulangan elemen berdasarkan data verbatim yang diperoleh. Hasil kajian menunjukkan terdapat lima tema yang menjadi ciri-ciri penting dalam pemilihan tajuk komunikasi yang bersesuaian dengan laras bahasa komunikatif. Ciri-ciri tersebut ialah aktiviti seharian pelajar yang menepati konteks mereka, nama-nama lokasi dan tempat, aspek yang berkaitan dengan geografi dan alam semula jadi, aspek sosial pelajar dan budaya yang berkisar pada kehidupan pelajar. Justeru, dapatan tema-tema dalam kajian ini diharap dapat memberi panduan yang lebih terperinci kepada penggubal kurikulum bahasa Arab tentang tajuk-tajuk yang sesuai dengan bidang laras bahasa komunikatif untuk dimuatkan dalam buku teks bahasa Arab komunikasi. Selain itu, dapatan kajian ini juga diharap dapat mengukuhkan teori terdahulu bahawa pengaruh konteks sosiobudaya tempatan dalam teks pembelajaran Arab dapat meningkatkan minat kepada pelajar untuk belajar bahasa.
\end{abstract}

Kata kunci: bahasa Arab komunikasi, laras bahasa komunikatif, modul bahasa Arab, bahasa ketiga

\section{Characteristics of the Suitability of Communication Titles in the Development of Arabic Language Teaching Modules: An Analysis of Communicative Language Register}

\begin{abstract}
Language register is a part of sociolinguistics. The appropriate selection of communicative language register will prompt the language teaching module more meaningful. This study aims to discover the characteristics of communicative title and title suitability based on communicative approach. The research approach is by applying expert interviews as the main method and supported by observational methods to obtain research data. The interview sample consisted of 8 expert lecturers. Data were coded, analyzed thematically, and described descriptively. The themes generated were based on the repetition of elements based on the verbatim data obtained. The results show that there are five themes that represent important features in the selection of communication topics that are appropriate to the
\end{abstract}


communicative language register. The characteristics are the daily activities of the students that conform to their context, the names of locations and places, aspects related to geography and nature, the social aspects of the students and the cultural aspects that revolve around their lives. Thus, the findings of the themes in this study are expected to provide more detailed guidance to Arabic language curriculum developers on topics that are appropriate to the field of communicative language to be included in the Arabic communication textbook. In addition, the findings of this study are also expected to strengthen the previous theory that the influence of local socio-cultural context in Arabic learning texts can increase students' interest in learning the language.

Keywords: Arabic language communication, communicative language register, development of Arabic language module, third language

\section{Pengenalan}

Laras dari segi bahasa ialah variasi atau ragam bahasa berdasarkan penggunaannya misalnya seperti bahasa klasik, bahasa istana atau bahasa sains" (Kamus Dewan, 2012:872). Laras juga boleh diertikan sebagai"...tech the words, style and grammar used by speakers and writers in particular conditions, official document are written a formal register" (Compact Oxford English Dictionary, 2002:875). Laras bahasa bermaksud kelainan bahasa yang digunakan mengikut bidang tertentu seperti bidang ilmu dan bidang sosial, bukan pada sistem bahasa semata-mata, laras bahasa yang berlainan yang digunakan bukannya pada sistem bahasa tetapi hanya pada kata-kata tertentu yang digunakan dalam laras (Asmah, 2008), berdasarkan konteks tertentu (Ab Razak, 2013). Laras juga diertikan sebagai jenis dan gaya bahasa tertentu yang digunakan dalam pertuturan (Ure \& Ellis, 1977). Pemakaian kata-kata tertentu yang bersesuaian dengan konteks (Abdullah Hassan, 1986). Ia merupakan ciri-ciri khusus penggunaan bahasa mengikut bidang sesuatu wacana digunakan. Laras bahasa boleh diertikan sebagai gaya atau cara menggunakan sesuatu bahasa dalam sesuatu situasi. Laras akan sentiasa berubah-ubah berdasarkan fungsi dan keadaan, setiap laras menitikberatkan pilihan kata atau istilah dan menggunakan struktur ayat yang berlainan mengikut disiplin atau bidang tertentu (Ab. Halim, 2008). Laras bahasa adalah variasi dan konvensi sosial atau lakuan bahasa sosial yang digunakan untuk sesuatu situasi di dalam masyarakat, selari dengan kewujudan situasi-situasi tertentu dan konteks penggunaan bahasa (Nur Hakimah, 2015).

Halliday (1973) mengklasifikasikan laras bahasa kepada tiga jenis iaitu pertama, berdasarkan kepada tajuk wacana iaitu tajuk, topik atau bidang yang dibualkan seperti laras bahasa perubatan; perkataan yang dibualkan hendaklah menepati laras bahasa yang berkaitan dengan perubatan. Kedua ialah cara penyampaian, sama ada wacana berkenaan di sampaikan secara lisan dan tulisan. Ketiga ialah gaya penyampaian juga telah dibincangkan dalam laras bahasa oleh Halliday iaitu dari segi gaya penyampaiannya sama ada bersifat formal atau tidak formal. Laras bahasa ialah salah satu daripada cabang sosiolinguistik, dalam ilmu sosiolinguistik, ragam bahasa diistilahkan sebagai register atau laras (Hudson, 1980). Lazimnya, pola-pola dan bentuk struktur ayat akan sentiasa bertukar dan berubah-ubah, ia akan dibentuk berdasarkan kepada tujuan dan matlamat yang tertentu. Laras bahasa wujud dan berubah berdasarkan kepada aspek umur, jantina serta tajuk-tajuk perbualan (Ure \& Ellis, 1977). Manakala Brian berpendapat bahawa laras perkataan dalam bidang tertentu berbeza di antara satu bidang dengan satu bidang yang lain. Maka tidak hairanlah seseorang itu akan memiliki pengetahuan berbahasa mengikut laras bahasa yang telah dia kuasai dalam proses pembelajaran dan kehidupan sebenarnya (Brian, 1982). Dalam kajian ini, kajian tertumpu kepada laras bahasa tajuk dan topik sahaja dalam bidang komunikasi.

Kesimpulannya, berdasarkan kepada semua definisi di atas, pengkaji merumuskan definisi untuk laras bahasa Arab komunikatif ialah seperti berikut : Laras bahasa Arab komunikatif adalah ciri-ciri khusus penggunaan bahasa, ia kerap digunakan dalam keadaan tertentu dan merupakan konvensyen sosial. Dengan menggunakan pelbagai corak laras, apa yang disebut sebagai variasi, gaya, ragam, konvensi dan bentuk dengan meraikan beberapa disiplin ilmu linguistik Arab, berdasarkan penggunaannya, pemakaian kata-kata tertentu yang bersesuaian dengan konteks, dan mengikut bidang sesuatu wacana 
yang digunakan, dalam kehidupan sehari-hari mengikut masa, situasi yang dikehandaki dan peristiwa bahasa itu berlangsung (Ibrahim, 2019).

\section{Sorotan Literatur}

Nik Safiah (2008) melihat kajian laras bahasa merangkumi variasi bahasa yang ditinjau dari segi penggunaan bahasa. Ia bermaksud bahawa seseorang individu menggunakan satu jenis pertuturan (satu laras) pada ketika dan situasi tertentu dan dia dapat memilih mana-mana laras yang sesuai dari salah satu senarai yang ada dalam dirinya. Begitu juga perubahan laras bahasa yang berlaku di dalam masyarakat Arab. Perlakuan bahasa dan pertuturannya akan berubah-ubah mengikut konteks dan situasi yang berbeza-beza.

Sehubungan itu, komunikasi mempunyai banyak tujuan yang memberi kesan secara langsung kepada laras bahasanya. Antara tujuan komunikasi ialah, membentuk hubungan sosial, memberi tindak balas terhadap sesuatu perkara, menyembunyikan niat dan perasaan, meminta dan memberi maklumat, mengajar melakukan sesuatu, perbualan melalui telefon, menyelesaikan masalah, membincang sesuatu idea, permainan bahasa, memainkan peranan kemasyarakatan, menggembirakan perasaan orang lain dan lain-lain (River \& Temperley, 1978).

Seperti yang kita maklum, dalam hal semasa berkomunikasi, manusia berbincang tentang banyak perkara. Keseluruhan kehidupannya boleh dijadikan tajuk perbualan dalam hubungan sesama mereka. Setiap agenda dituturkan mempunyai tujuan serta maksud yang tertentu yang ingin dicapai oleh penutur. Penutur menggunakan laras-laras tertentu dalam pelbagai ragam bahasa dan pelbagai gaya bahasa bagi tujuan komunikasi supaya maksud yang hendak disampaikan itu tercapai. Penutur yang kreatif akan dapat memanipulasikan sesuatu bahasa dengan baik, malah ia mampu menggunakan laras sesuatu bahasa dengan baik dan tepat. Antara laras bahasa yang ada ialah laras bahasa komunikasi, laras bahasa ekonomi, laras bahasa sejarah, laras bahasa perubatan, laras bahasa sains dan lain-lain (Ab Razak Ab Karim, 2008).

Menurut pengkaji tempatan Asmah (2008) pula, laras bahasa bukan bermaksud perbezaan sistem bahasa tetapi perbezaan yang berlaku terhadap istilah-istilah khusus atau tertentu terhadap penggunaan bahasa. Beliau menekankan bahawa laras yang berlainan yang digunakan dalam komunikasi bukannya pada sistem bahasa, tetapi ia merujuk kepada kata-kata tertentu yang digunakan dalam laras. Antara ciri-ciri khusus dalam penggunaan bahasa ialah menurut bidang, di mana terdapat perbezaan variasi bahasa mengikut disiplin ilmu yang bermacam-macam. Laras bahasa ada perkaitan dengan bentuk gaya bahasa dan penggunaan sesuatu bahasa, penggunaan sesuatu bahasa akan berubah serta mengikut konteks, bidang dan juga peringkat sosial (Nik Safiah, 2008; Abdullah Hassan, 1989; Ibrahim, 2019).

\section{Bahasa Arab Komunikasi}

Istilah komunikasi atau dalam bahasa Inggerisnya disebut Communication berasal dari bahasa Latin "communicatio" dan bersumber dari kata communic yang ertinya "membuat kebersamaan atau membangun kebersamaan antara dua orang atau lebih". Menurut Rogers dan Kincaid (1981), komunikasi adalah suatu proses di mana dua orang atau lebih membentuk atau melakukan pertukaran informasi antara satu sama lainnya, sehingga tercipta atau terhasil hubungan saling memahami dan saling mengerti.

Maka, dalam kajian ini Bahasa Arab Komunikasi ialah satu pendekatan pengajaran bahasa Arab standard yang mengutamakan kemampuan pelajar untuk berkomunikasi dalam bahasa Arab yang terdiri dari dua orang atau lebih. Komunikasi yang dimaksudkan adalah suatu proses pertukaran informasi supaya dapat membentuk satu perhubungan sosial dalam kalangan mereka (Ibrahim, 2019). Nurasyikin (2020) menjelaskan bahasa Arab standard adalah sangat penting untuk dikuasai sekiranya ingin menguasai ilmu berbahasa Arab yang lain. 


\section{Modul Pengajaran Bahasa}

Dalam usaha untuk mencapai kompetensi komunikatif dalam pembelajaran bahasa Arab di Malaysia, buku teks dan modul dianggap sebagai sumber rujukan utama bagi guru dan juga pelajar. Dalam pengajaran dan pembelajaran bahasa Arab di Malaysia, pelajar dan guru kebiasaannya akan selalu menjadikan buku teks sebagai medium rujukan utama mereka (Salahuddin et al., 2017). Ini membuktikan buku teks merupakan salah satu faktor penting yang berfungsi secara langsung dalam menentukan tahap pencapaian kompetensi komunikatif dalam kalangan pelajar yang mempelajarinya (Kamarudin, 1995).

Namun begitu, isu kelemahan pelajar dalam menguasai kompetensi komunikatif yang dikaitkan dengan bahan pembelajaran telah dibincangkan oleh ramai sarjana. Mansoer (1991) menjelaskan antara punca permasalahan pengajaran dan pembelajaran bahasa adalah terdapat penggunaan buku teks yang kurang sesuai, di samping masalah lain juga seperti masalah sikap, minat, motivasi, ingatan, bahan rujukan tambahan, masa, kurikulum, guru dan pelajar. Lazimnya, kebanyakan buku teks komunikasi yang ada, tidak mencapai objektif sukatan pelajaran dan tidak bersesuaian dengan konteks semasa pelajar. Latihan pula tidak disediakan secara rapi. Malah, laras bahasa dalam bahan pengajaran komunikatif misalnya, tidak mempunyai ciri-ciri bahan komunikasi yang sebenar, kosa kata yang dipilih juga tidak sesuai dengan kehendak pelajar dan konteks mereka. Kesannya, hasrat akhir pembelajaran dengan sendirinya terhalang dan tidak tercapai seperti yang dirancangkan (Mansoer, 1991). Menurut Lily (2021), kelemahan pelajar berkaitan juga dengan keterbatasan penguasaan perbendaharaan kata. Pembelajaran kolokasi berasaskan sumber data korpus boleh menghasilkan bahan bahasa Arab yang autentik.

\section{Permasalahan Kajian}

Berdasarkan keterangan di atas, beberapa dapatan kajian lepas berkaitan buku teks dan modul pengajaran bahasa Arab komunikasi dirujuk dan membuktikan bahawa kebanyakan pemilihan kandungan bahan pengajaran bahasa Arab dalam buku teks tidak bercirikan komunikatif. Misalnya, teks bacaan yang dimuatkan dalam buku adalah terlalu panjang, sehingga guru banyak menghabiskan masa melakukan penterjemahan di dalam kelas. Kesannya, masa pembelajaran untuk melakukan aktiviti berkomunikasi dalam bahasa yang dipelajari menjadi terbatas dan terhad (Al Muslim \& Zamri, 2015). Selain itu, terdapat juga buku teks yang dibina tidak berpusatkan pelajar, apabila tajuk serta isi kandungannya adalah tidak selari dengan minat pelajar. Isi kandungannya pula tidak setaraf dengan tahap pemikiran mereka (Ibrahim, 2003). Masalah sebegini sudah pasti akan menjadi kekangan bagi mencapai objektif dalam PdP yang berorientasikan pendekatan komunikatif. Arnida (2021) menjelaskan bahan pengajaran hendaklah mempunyai unsur budaya supaya pelajar dapat menguasai bahasa dengan lebih berkesan.Ini bermakna bahan pengajaran komunikatif yang dimuatkan dalam sesebuah buku teks perlu diberi perhatian sewajarnya agar elemen fungsian, nasional, dan budaya dapat disusun dengan baik berdasarkan tajuk yang sesuai dengan ciri-ciri komunikatif. Di samping itu, elemen ini juga boleh digabungkan bagi menonjolkan pendekatan komunikatif yang ingin diterapkan (Littlewood, 1981).

\section{Objektif Kajian}

i. Mengetahui ciri-ciri tajuk komunikatif yang sesuai untuk dimuatkan dalam buku teks komunikasi Bahasa Arab.

ii. Mengenal pasti kesesuaian tajuk dalam buku teks Bahasa Arab Komunikasi berdasarkan pendekatan komunikatif.

\section{Metod Kajian}

Kajian ini menggunakan kaedah kualitatif yang menggunakan temu bual sebagai kaedah utama bagi memperoleh data kajian. Data dikodkan dan dihuraikan secara deskriptif dan tematik. Selain data temu 
bual, kajian ini juga disokong oleh kaedah pemerhatian, tujuan pemerhatian ialah untuk melihat fenomena secara langsung dan menggunakan pengetahuan, pengalaman dan kepakarannya merekodkan perlakuan yang sedang berlaku (Patton, 2002).

\section{Sampel Kajian}

Kajian ini memilih pensyarah pakar sebagai sampel utama kajian. Jumlah sampel untuk temu bual pakar ialah sebanyak lapan (8) orang responden. Manakala alat kajian yang digunakan dalam kajian ialah satu set soalan temu bual untuk temu bual pensyarah pakar bahasa Arab dan satu set buku komunikasi al Lughatul al 'Arabiyyat al ittisāliyyat. Data temu bual pakar dianalisis menggunakan Atlas ti-8 dan dihuraikan secara tematik, kemudian dihuraikan secara deskriptif. Seterusnya analisis kandungan dilakukan bertujuan untuk melihat frekuensi dan kekerapan penggunaan uslub komunikasi dalam buku teks. Akhir sekali data digabungkan dan dihuraikan secara triangulasi bagi memperolehi dapatan kajian.

Pensyarah pakar yang dipilih yang mempunyai pengalaman mengajar 15 tahun dan ke atas sahaja, serta dijadikan asas kepada pemilihan responden pakar. Walaupun untuk tempoh pengalaman mengajar pula, KPM telah menetapkan 9 tahun tahap minimum untuk tempoh kelayakan asas seorang guru menjadi guru pakar mereka. Manakala, dari aspek keilmuan, pengkaji telah menetapkan pensyarah yang mempunyai $\mathrm{PhD}$ sebagai syarat profesional dan ukuran pencapaian akademik responden. Semua responden dipilih daripada jurusan bahasa Arab sahaja dan bermula daripada pensyarah kanan dan ke atas sebagai memenuhi ciri-ciri ketokohan dan kepakaran mereka dalam bidang pengajaran dan pembelajaran bahasa Arab. Maka, melalui pemilihan responden yang teliti dan rumit tersebut, diharapkan akan mendapat hasil kajian yang mempunyai nilai yang tinggi daripada pensyarah yang berpengalaman, seperti yang dijelaskan oleh Fraenkel dan Wallen, (1996), satu dapatan yang bersifat defensibility, accuracy, appropriatetness, meaningfulness, usefulness.

\section{Kesahan dan Kebolehpercayaan}

Soalan temu bual pakar pensyarah pakar yang berkaitan dengan kajian buku teks Bahasa Arab Komunikasi di UiTM yang digunakan dalam kajian ini, terlebih dahulu dibuat pengesahan pakar untuk mendapat maklumat secara terperinci tentang tajuk komunikatif, ciri kosa kata komunikatif dan ciri uslub komunikatif dan skema pemarkahan serta jawapannya telah disahkan oleh empat orang pensyarah pakar yang dilantik. Mereka yang mempunyai pengalaman dalam PdP bahasa Arab melebihi 20 tahun. Semua item temu bual telah disemak dan disahkan oleh empat orang pakar bahasa bagi tujuan kesahan dan kebolehpercayaan:

i. Pakar rujuk bahasa pertama, merupakan seorang pensyarah kanan bahasa Arab di Universiti Malaya. Beliau berkelulusan Ijazah Doktor Falsafah dalam bidang bahasa Arab dari Universiti Malaya.

ii. Pakar rujuk bahasa kedua, merupakan seorang tenaga pengajaran di Universiti Malaya. Beliau memperoleh Ijazah Doktor Falsafah dari Universiti Malaya.

iii. Pakar rujuk bahasa ketiga, merupakan seorang Profesor Madya dalam bahasa Arab di Universiti Malaya. Beliau mempunyai Ijazah Doktor Falsafah dari Oxford Academy \& Janub Al-Wadi, Mesir (2000).

iv. Pakar rujuk bahasa yang keempat, seorang Profesor Madya di Universiti Teknologi MARA dalam bidang bahasa Arab selama 28 tahun. Berkelulusan Ijazah Doktor Falsafah dalam bidang yang sama dari Universiti Malaya (2003).

\section{Tatacara Analisis Data}

Kajian ini menggunakan kaedah pendekatan kualitatif. Dalam kaedah temu bual, proses pengumpulan data sebenarnya berlaku serentak dengan proses penganalisisan data. Pengkaji berbuat demikian untuk mengelakkan kehilangan beberapa maklumat penting yang disebabkan oleh lambakan data. Dalam pendekatan kualitatif, pengkaji melakukan analisis temu bual seperti yang dicadangkan oleh Miles dan Huberman (1994:278), iaitu menganalisis data temu bual dengan mengenal pasti tema-tema tertentu yang ditekankan (Tematik). 
Selepas selesai menemu bual responden pakar 1 (RP1), pengkaji mentranskripkan temu bual tersebut menggunakan Microsoft Word. Pengkaji telah membaca data dengan teliti, setiap perkataan yang tercatat, telah dipastikan keasliannya. Maka tiada ada perkataan yang tertinggal dari setiap yang dituturkan oleh responden. Kemudian, hasil transkrip diserahkan kepada RP1 untuk disemak isi kandungannya. Setelah RP1 berpuas hati dengan hasil kerja tersebut, RP1 menandatangani transkrip tersebut untuk tujuan kesahan. Seterusnya, pengkaji mula melakukan proses coding data menggunakan perisian ATLAS Ti8. Pengkaji membaca transkrip dengan teliti, kemudian mengenal pasti tema dan seterusnya membentuk satu kod bagi setiap kategori yang ditemui. Kemudian, menguruskan data dengan cara mengasingkan unit-unit mengikut kategori dan akhirnya membina koding. Semua koding yang dihasilkan dilakarkan secara grafik dalam bentuk network. Network yang ada menunjukkan perkaitan antara kod-kod dengan tema.

Setelah selesai temu bual RP1, pengkaji menemu bual pula responden pakar 2 (RP2). Pengkaji melakukan prosedur yang sama seperti RP1. Apabila pengkaji mendapati koding yang baru pada tematema tertentu secara berulang, maka, pengkaji akan memberi perhatian kepada koding lain atau tema lain yang masih memerlukan data. Teori penepuan juga digunakan dalam temu bual kajian. Sebagai contoh, penepuan dalam kajian ini ialah pengkaji menggunakan data temu bual sebanyak 8 informan berdasarkan justifikasi berikut. Pertama, setiap informan mewakili seorang (1) responden pakar dalam bidang Bahasa Arab Komunikasi. Kedua, hasil temu bual informan kajian menunjukkan data temu bual yang menghasilkan kod-kod baharu sekiranya terdapat data yang baharu diperoleh daripada informan. Apabila data yang diperoleh berulang-ulang pada informan ke 4, ke 5, ke 6 dan ke 7, ini menunjukkan bahawa data yang dikumpulkan telah mencapai tahap penepuan. Bermakna, hanya maklumatmaklumat yang sama sahaja didapati daripada informan pada masa itu. Situasi ini menunjukkan jumlah informan untuk kaedah temu bual dalam kajian ini telah pun mencukupi dan relevan untuk tujuan pengumpulan data kajian.

Dalam analisis Atlas Ti 8, rajah akan menghasilkan kod-kod bagi tema seperti berikut, ia membawa maksud yang tertentu, iaitu; (D1: R1 ialah dokumen 1 daripada responden 1), (D2: R2 ialah dokumen 2 daripada responden pakar 2), (D3: R3 ialah dokumen 1 daripada responden pakar 3), (D4: R4 ialah dokumen 4 daripada responden pakar 4), (D5: R5 ialah dokumen 5 daripada responden pakar 5), (D6: R6 ialah dokumen 6 daripada responden pakar 6), (D7: R7 ialah dokumen 7 daripada responden pakar 7), (D8: R8 ialah dokumen 8 daripada responden pakar 8) dan (D9: R2 ialah dokumen 9 daripada responden pakar 2). Sebagai contoh seperti simbol ini ( $\mid \mathrm{D}$ D:R8 $\mid$ ) dalam rajah analisis, D8 bermaksud dokumen yang kelapan dan R8 pula bermaksud responden pakar kelapan.

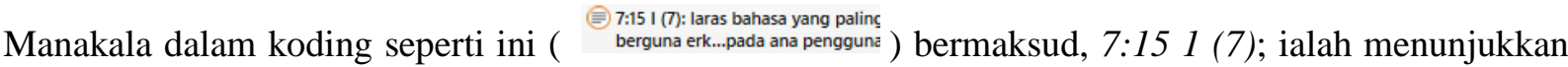
tema tertentu yang tercatat dalam dokumen 7, angka 15 ialah bukti pertuturannya berada pada baris ke15 dalam transkripsi dokumen temu bual tersebut, angka 1 ialah kekerapan temu bual dibuat dengan responden pakar yang ketujuh.

Akhirnya, dapatan akan ditulis secara deskriptif yang melibatkan aktiviti mengekod dan meringkaskan data yang diperoleh daripada pemprosesan data. Paparan data deskriptif disajikan dalam bentuk gambar rajah dan huraian.

\section{Hasil Kajian}

Untuk menjawab persoalan kajian yang pertama dan kedua, dinyatakan beberapa protokol soalan yang berkaitan bagi menjawab persoalan pokok di atas, iaitu :

i. Apakah tajuk-tajuk komunikatif yang sesuai untuk dimuatkan dalam buku teks Bahasa Arab Komunikasi?

ii. Pada pandangan saudara, sejauh mana tajuk komunikatif membantu proses pemerolehan bahasa di kalangan pelajar?

iii. Pada pandangan anda, apakah tajuk yang anda rasa sesuai dengan konteks sosial pelajar dan sesuai untuk dimuatkan dalam buku teks Bahasa Arab Komunikasi? 
iv. Pada pandangan anda, apakah tajuk yang anda rasa sesuai dengan konteks budaya pelajar dan sesuai untuk dimuatkan dalam buku teks Bahasa Arab Komunikasi?

\section{Dapatan Objektif Kajian Pertama}

Berdasarkan dapatan analisis temu bual pakar, pada soalan protokol di atas maka dapat dijelaskan lima tema bagi menjelaskan ciri-ciri tajuk komunikasi yang sesuai diletakkan dalam buku teks komunikasi. Lima utama ini dapat menjawab persoalan kajian yang pertama iaitu "Apakah ciri-ciri tajuk komunikatif yang sesuai untuk dimuatkan dalam buku teks komunikasi Bahasa Arab?”. Antara tema yang terhasil daripada pengekodan data temu bual ialah seperti berikut :

i. Tema 1: Aktiviti seharian pelajar yang selari dengan konteks pelajar sesuai dijadikan tajuk komunikatif.

ii. Tema 2: Aspek lokasi dan tempat boleh dijadikan sebagai tajuk komunikatif.

iii. Tema 3: Perbualan mengenai aspek geografi seperti cuaca dan masa boleh dijadikan sebagai tajuk komunikatif.

iv. Tema 4: Aspek konteks sosial seharian pelajar sesuai dijadikan tajuk komunikatif.

v. Tema 5: Tajuk budaya yang sesuai untuk buku teks ialah budaya yang berkisar tentang kehidupan sosial bagi masyarakat Malaysia seperti makanan, pakaian, permainan dan perkahwinan.

Kesimpulan dari dapatan tema ini, menunjukkan bahawa pandangan pakar mendapati antara bidang laras bahasa komunikasi yang wajar diberi perhatian semasa pembinaan modul adalah aspek aktiviti seharian pelajar, aspek lokasi, aspek geografi, konteks sosial seharian dan seterusnya budaya yang sesuai dengan kehidupan pelajar. Dapatan ini menyokong pandangan Littlewood (1981) yang menggalakkan penggunaan elemen fungsian, nasional, dan budaya yang dapat disusun dengan baik berdasarkan tajuk yang sesuai dengan ciri-ciri komunikatif.

\section{Dapatan Objektif Kajian Kedua}

Dapatan menjelaskan analisis temu bual bagi menjawab persoalan kajian kedua iaitu: Apakah tajuktajuk komunikatif yang sesuai untuk dimuatkan dalam buku teks Bahasa Arab Komunikasi?. Pada bahagian ini dijelaskan teks perbualan responden dan rajah hubungan hasil pengekodan Atlas Ti 8 sebagai bukti dapatan.

Tema 1: Aktiviti seharian pelajar yang selari dengan konteks pelajar sesuai dijadikan tajuk komunikatif.

Dapatan analisis temu bual pakar menunjukkan lima responden iaitu responden 1 (R1), 2 (R2), 3 (R3), 4 (R4), 5 (R5) bahawa aktiviti seharian pelajar atau setiap aktiviti yang mencakupi aspek konteks pelajar amat sesuai dijadikan sebagai tajuk dalam buku teks Bahasa Arab Komunikasi. Berdasarkan rajah 1, antara aktiviti yang disebut ialah perkelahan, bersukan, memasak, pengembaraan, membeli belah, ibadah, percutian, membaca, hobi, permainan, belajar dan menonton tv. Contoh ungkapan responden 1 (R1), 2 (R2), 3 (R3), 4 (R4) dan 5 (R5) mengatakan:

I(1): aaa..ok..berkenaan dengan tajuk ni... ana rasa tajuk yang sesuai al-hayah al-jāmi'iyyah, alittisāliyyah wa al-intarnīt, a-riyādhah, al-rehlah wa al-safar, aaa...apa lagi ya... ok..almuqābalah, aaa.. pastu macam tajuk al-mu'āmalāh al-yawmiyyah, al-amākin alsiyāhiyyah...aaa satu lagi tu...ok al-thaqāfät al-islāmiyyah...aaa ...banyak la lagi..tu antara yang sesuai la dengan budak-budak (pelajar) kita ...sebab semua tu...kiranya..dok berlaku laa dalam kehidupan mereka sehari-hari....aaa kan...?!!

I(2): pada ana la ...aaa ....tajuk ni mesti sesuai dengan konteks pelajar, jadi pelajar biasanya terdiri daripada orang muda.. pada pandangan ana..aaa...tajuk permainan, bersukan, perkelahan, percutian... ana rasa tajuk-tajuk macam ni..sesuai sangat jika nak diletakkan dalam buku teks..

I(3) : aaa...pada pandangan ana ...tajuk yang sesuai tu banyak la... macam permainan kan al-lu'bah, al Siyahah..melancong..tak kira lah dalam atau luar Negara...sebab benda ni seronok..bila seronok..pelajar akan suka nak belajar sikit kan ....haha...tajuk bersukan pun penting jugak la.. 
sebab hari hari main bola katakana ...jadi benda yang selalu dibuat akan mudah la pelajar nak ingat nanti... aaa itu lah dia...haha...

I(4): aaa... tajuk permainan, travel contohnya kan....aaa...kalu nak bincang berat sikit..tajuk politik, PBB ke...haha...seronok tu...(ketawa)

I(5): aaa... kita boleh buat tajuk yang ada kaitan dengan aktiviti kita seharian, macam beriadah, hobi-hobi macam membaca...aaa...kalau tajuk cuaca pun penting juga sebab...aaa kita kan selalu berdepan dengan macam-macam jenis cuaca tiap-tiap hari...aaa..kan penting tu...haha..aaa..tajuk pekerjaan pun penting..tajuk di airport..aaa melancong aaa...lagi satu ...tajuk yang tak ada dalam buku teks UiTM, saya tengok ialah tajuk masa ...aaa.. tajuk masa ni actually kan..penting sangat kot..tapi kenapa tajuk ni taka da..jadi nanti pelajar tak reti la nak guna zorof zaman tu...kan.

Rajah 1: Hubungan Tajuk Berbentuk Aktiviti Pelajar dengan Laras Bahasa Komunikatif

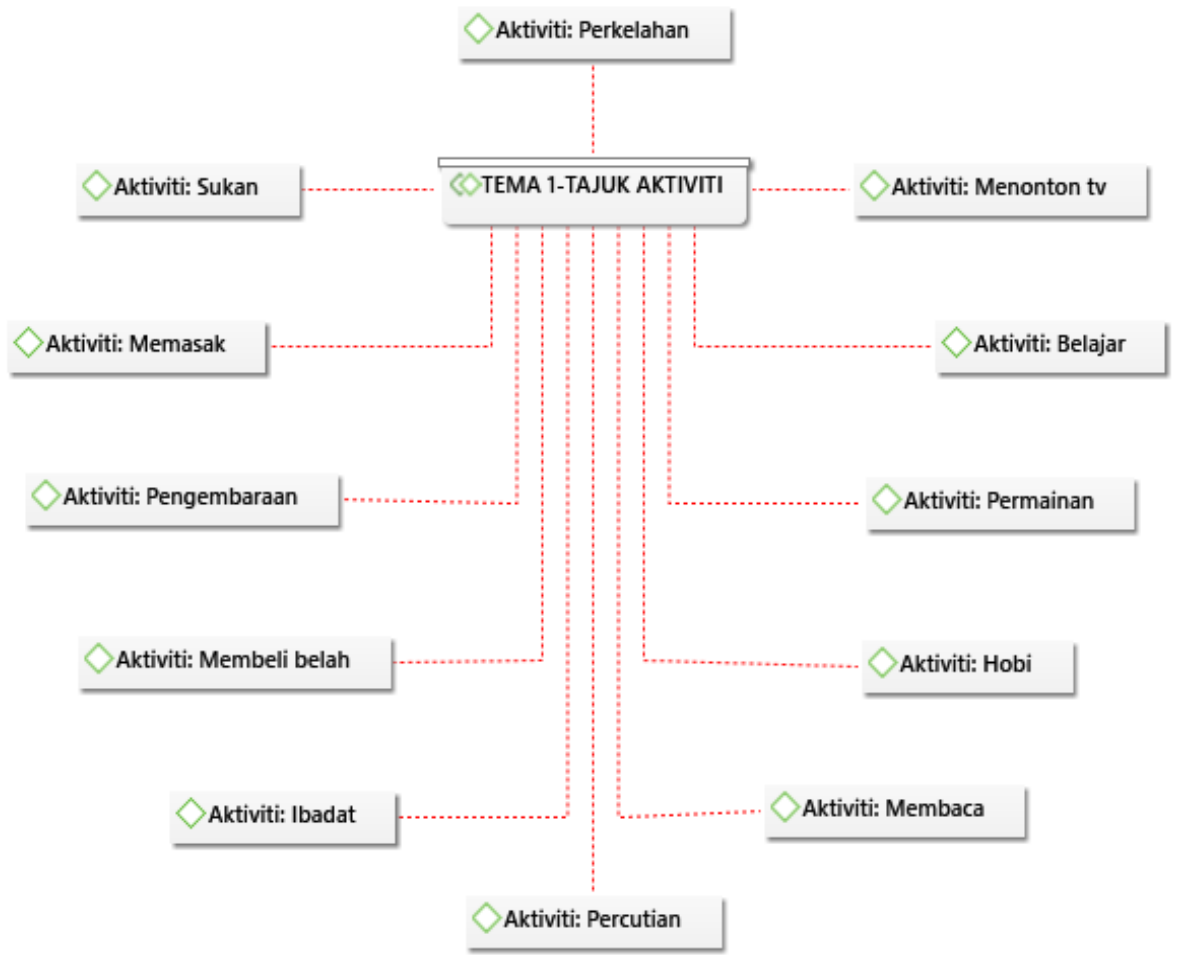

Tema 2: Aspek lokasi dan tempat boleh dijadikan sebagai tajuk komunikatif

Dapatan analisis temu bual pakar menunjukkan lima responden iaitu responden 3 (R3), 4 (R4), 5 (R5), 7 (R7) dan 8 (R8) bahawa tempat atau lokasi berlakunya aktiviti seharian pelajar amat sesuai dijadikan sebagai tajuk dalam buku teks Bahasa Arab Komunikasi kerana bertepatan dengan konteks sosial pelajar. Berdasarkan rajah 2, antara lokasi yang dicadangkan ialah di pejabat, di lapangan terbang, di balai polis, di kaunter, di klinik, di hospital, di pasaraya, di bank, di restoran, di hotel, di universiti, di kedai, di stesen dan di pasar. Contoh ungkapan daripada responden 3 (R3), 4 (R4), 5 (R5), 7 (R7) dan 8 (R8) ialah:

I(3) : tajuk komunikatif ni ..aaa...membantu la proses pembelajaran bahasa tu...aaa..sebabnya la saya rasa.tajuk ni akan jadi role model tuk bercakap...aaa.. sebagai satu fenomena soisal aaa...macam tajuk di restoran, di supermarket atau mall yang besar-besar tu, di restoran atau di pasar ikan ke...yang cuba dibuat dalam kelas...jadi..situasi atau fenomena ni sangat penting la.dan sangan membantu pelajar .... Dalam pemerolehan bahasa Arab..wallahua'lam..

I(4): oohh..secara umumnya memang la membantu proses pemerolehan bahasa tu...aaa.. student ni..bila kita nak bercakap dengan mereka la kan ...perlu ada tajuk yang sesuai..aaa..tul tak?.. lebih-lebih lagi la dalam bahasa Arab...aaa..antara contoh tajuk komunikatif ni... di balai polis, 
di klinik atau di spital (hospital), di hotel ka...di ruang pameran...di stesen bas... di pasar...pada ana lah.. banyak yang boleh disesuaikan untuk tajuk...aaa...sangat membantu la...aaa...sebab kemungkinan dengan tajuk komunikatif tu..pelajar akan dapat la..ungkapkan apa yang ada dalam mindanya tu...aaa..dapat belajar la bagaimana nak luah kan perasaanny..aaa..

I(5): ...aaa..tajuk pekerjaan pun penting..tajuk di airport..aaa melancong aaa...lagi satu ...tajuk yang tak ada dalam buku teks UiTM, saya tengok ialah tajuk masa...aaa.. tajuk masa ni actually kan..penting sangat kot..tapi kenapa tajuk ni taka da..jadi nanti pelajar tak reti la nak guna zorof zaman tu...kan..(senyum)

I(7): ...saya rasa kita boleh masukkan tajuk membeli belah, di pejabat fakulti, di stadium atau di taman untuk bersukan ...mmm ... sebab pelajar lalui kan semua tu dalam hidup dia ...kan...

I(8): ooo...tajuk yang ok sikit la dengan konteks student ni..seperti tajuk ibadah, pakaian ...aaa ...tajuk cuaca...kuliah, pengangkutan ...aaa tajuk mall.

Rajah 2: Hubungan Lokasi Sebagai Tajuk Komunikatif

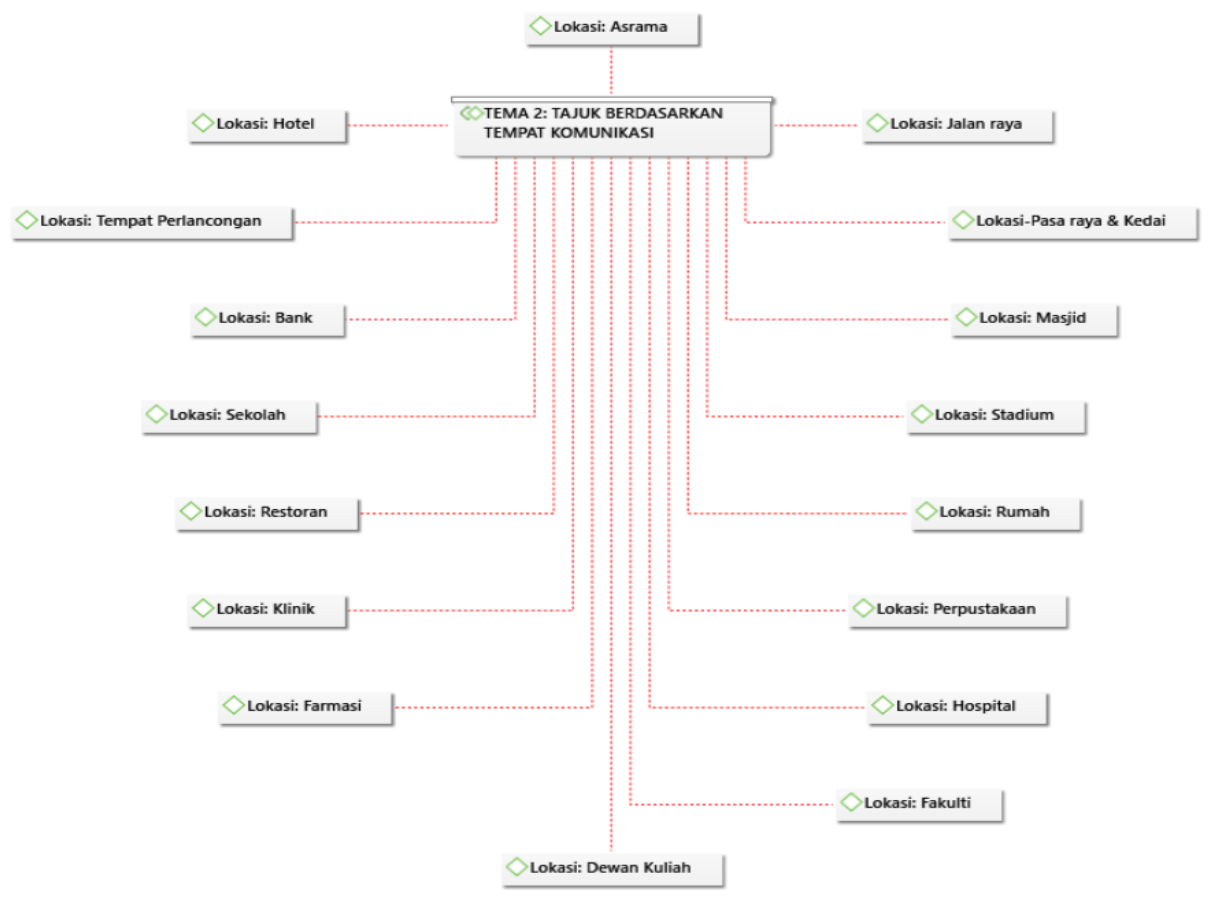

Tema 3: Perbualan mengenai aspek geografi seperti cuaca dan masa boleh dijadikan sebagai tajuk komunikatif.

Dapatan analisis temu bual pakar menunjukkan lima responden iaitu responden 5 (R5) dan 8 (R8) bahawa aspek cuaca dan masa sering berlaku dalan konteks sosial pelajar. Maka beberapa orang pakar telah mencadangkannya sebagai tajuk komunikatif. Contoh ungkapan daripada responden 5 (R5) dan 8 (R8) ialah:

I(5): ...aaa..tajuk pekerjaan pun penting..tajuk di airport..aaa melancong aaa...lagi satu ...tajuk yang tak ada dalam buku teks UiTM, saya tengok ialah tajuk masa...aaa.. tajuk masa ni actually kan..penting sangat kot.tapi kenapa tajuk ni taka da..jadi nanti pelajar tak reti la nak guna zorof zaman tu...kan..(senyum)

I(8): ooo...tajuk yang ok sikit la dengan konteks student ni..seperti tajuk ibadah, pakaian ...aaa ...tajuk cuaca ...kuliah, pengangkutan ...aaa tajuk mall. 
Tema 4: Aspek konteks sosial seharian pelajar sesuai dijadikan tajuk komunikatif

Seterusnya bagi jawapan temu bual bagi soalan kedua untuk tajuk iaitu, "Pada pandangan anda, apakah tajuk yang anda rasa sesuai dengan konteks sosial pelajar dan sesuai untuk dimuatkan dalam buku teks Bahasa Arab Komunikasi?". Satu tema telah dikeluarkan. Tema tersebut ialah aspek konteks sosial seharian pelajar sesuai dijadikan tajuk komunikatif .

Rajah 3: Hubungan Tajuk Komunikatif Berdasarkan Konteks Sosial

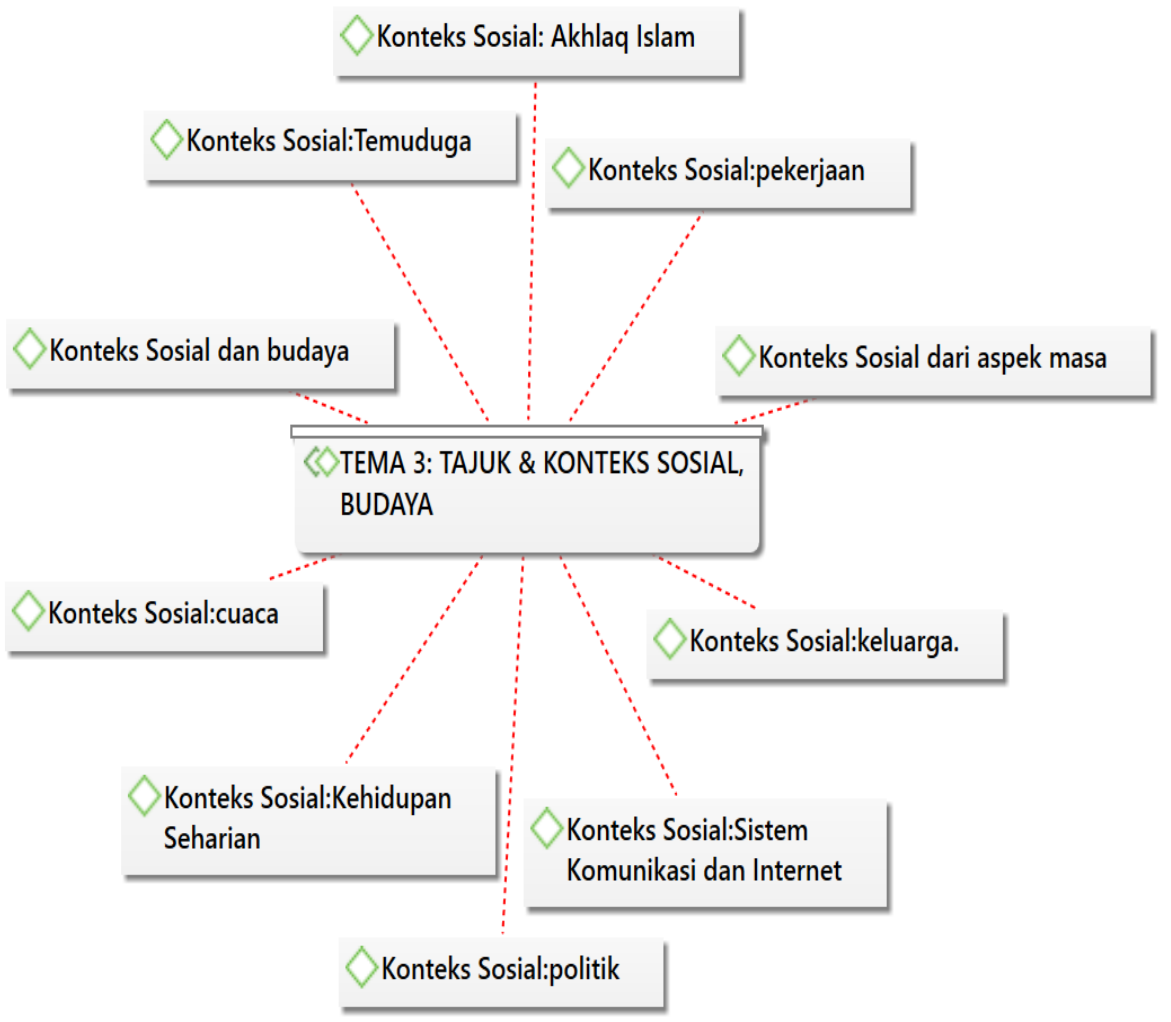

Dapatan analisis temu bual pakar menunjukkan lima responden iaitu responden 1 (R1), 3 (R3), 4 (R4), 6 (R6) dan 7 (R7) bahawa konteks sosial mempunyai peranan penting dalam pemilihan tajuk komunikasi. Berdasarkan rajah 3 di atas, analisis menunjukkan antara tajuk dan bidang komunikasi yang sesuai dengan konteks pelajar ialah konteks pekerjaan, akhlaq Islam, kekeluargaan, kehidupan seharian, alam semula jadi seperti cuaca, isu semasa seperti politik, media sosial seperti internet dan sosial budaya dalam masyarakat. Contoh ungkapan daripada responden 1 (R1), 3 (R3), 4 (R4), 6 (R6) dan 7 (R7)ialah:

"I (2): bagi saya ...aaa... sangat penting la tajuk sosial ni...budak kalu baca ja tajuk yang sesuai dengan konteks dan jiwa nya...aaa..rasa senang la depa nak study...macam...tajuk berbentuk komunikasi seperti sosial dan budaya setempat, family dan sebagainya... kena ada dalam buku teks ..sebab pelajar jelas apa yang mereka akan belajar..."

"I (3) : pelajar suka la kalau tajuk percutian ...aaa ...tajuk yang berbentuk konteks sosial...sebab dari kecil lagi, mereka dibawa bercuti oleh ibu bapa, tajuk makan dan minuman ka...sebab mereka setiap hari makan dan minum dengan keluarga mereka, kawan-kawan kan... tajuk media sosial pun macam ok juga...sebab...sekarang kan zaman IT...ana rasa sesuai dengan konteks jugak.."

"I (4): oohh..secara umumnya memang la membantu proses pemerolehan bahasa tu...aaa.. student ni..bila kita nak bercakap dengan mereka la kan...perlu ada tajuk yang sesuai..aaa..seperti masa, cuaca dan pekerjaan..." 
"I (6): ya la..tajuk komunikatif penting la kan...kalu tajuk Usrah... apa tu..aaa..family la katakan..aaa..dalam buku teks..pelajar secara tidak langsung ...aaa...dapat membina kemahiran bahasa pelajar dengan kosa kata yang berkait dengan tajuk tu..k ..."

"I (7): saya rasa kita boleh masukkan tajuk kehidupan seharian ...contohnya la ye...solat...akhlaq islamiyyah, bersukan...atau politik...mmm... sebab pelajar lalui kan semua tu dalam hidup dia...kan..."

Tema 5: Tajuk budaya yang sesuai untuk buku teks ialah budaya yang berkisar tentang kehidupan sosial bagi masyarakat Malaysia dan Arab seperti makanan, pakaian, permainan dan perkahwinan.

Berdasarkan rajah 4 dibawah, menunjukkan satu tema bercirikan tajuk budaya yang sesuai untuk pembinaan modul dan buku teks terhasil.

\section{Rajah 4: Tajuk Komunikatif Berdasarkan Budaya}

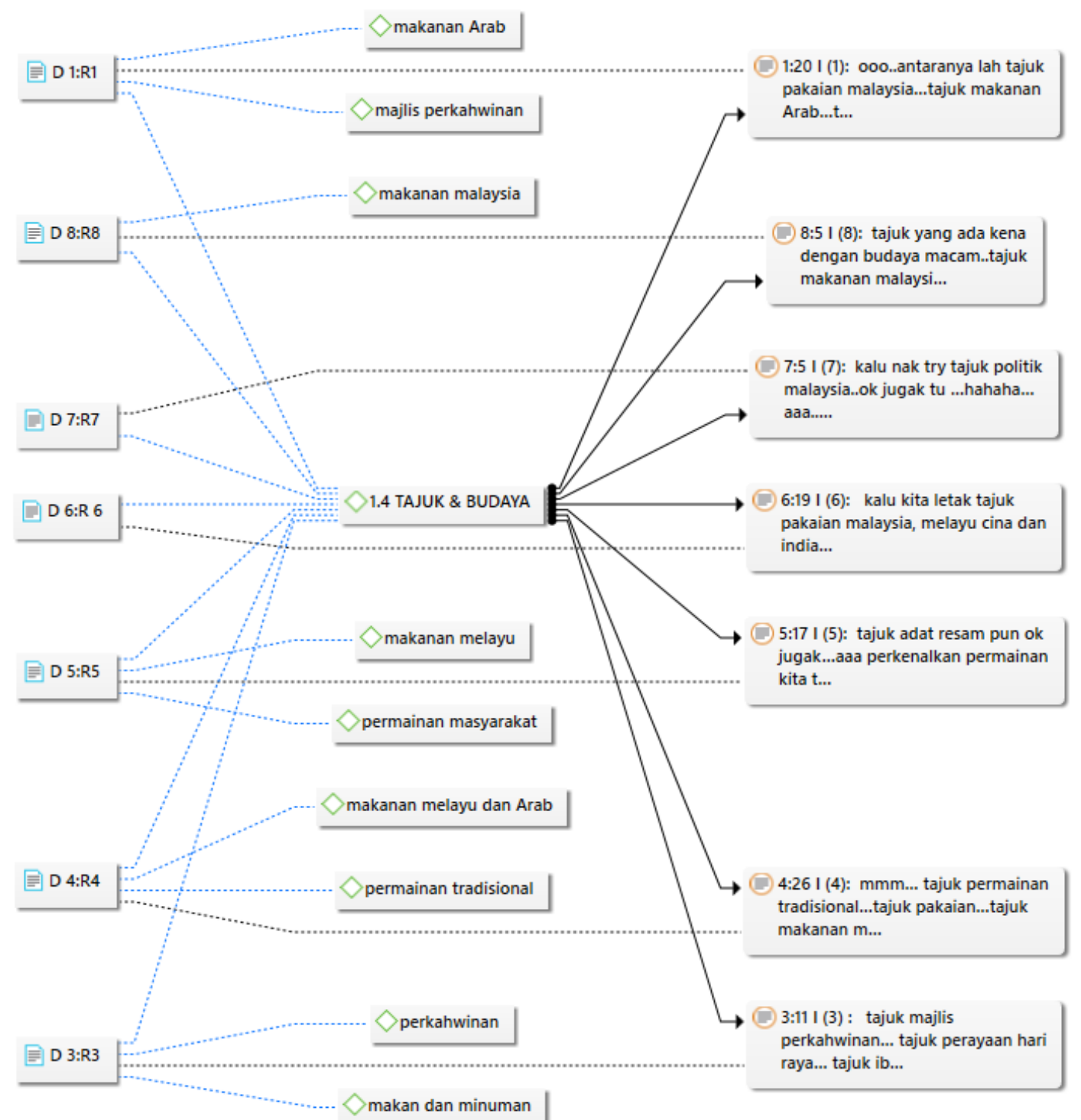

Dapatan analisis ATLAS Ti8 menjelaskan bahawa aspek budaya yang dimaksudkan adalah yang berkisar tentang kehidupan sosial bagi masyarakat Malaysia dan Arab seperti makanan, permainan, pakaian dan perkahwinan. Dapatan analisis temu bual pakar menunjukkan lima responden iaitu responden 1 (R1), 3 (R3), 4 (R4), 5 (R5), 6 (R6), 7 (R7) dan 8 (R8) bahawa aspek budaya mempunyai peranan penting dalam pemilihan tajuk komunikasi. Analisis menunjukkan antara tajuk dan bidang komunikasi yang sesuai dengan konteks budaya pelajar ialah budaya makanan Arab dan Malaysia, budaya perkahwinan Arab dan Malaysia, budaya adat resam, permainan rakyat atau permainan 
tradisional dan budaya kekeluargaan. Contoh ungkapan daripada responden 1 (R1), 3 (R3), 4 (R4), 5 (R5), 6 (R6), 7 (R7) dan 8 (R8) ialah:

"I (1): ooo..antaranya lah tajuk pakaian malaysia...tajuk makanan Arab...tajuk perayaan la..hari raya atau tajuk majlis perkahwinan pun ok gak.."

"I(3) : tajuk majlis perkahwinan... tajuk perayaan hari raya... tajuk ibadah dan agama ...aaa ...banyak lagi lah..",

"I (4): mmm... tajuk permainan tradisional...tajuk pakaian...tajuk makanan melayu dan Arab...aaa ...perayaan raya kita.."

"I(5): tajuk adat resam pun ok jugak...aaa perkenalkan permainan kita tajuk permainan masyarakat malaysia ...aaa ...tajuk pakaian dan makanan melayu, sambutan raya"

"I (6): Kalu kita letak tajuk pakaian malaysia, melayu cina dan india..ok tu..sebab banyak budaya boleh dimasukkan...dan boleh jugak la tajuk perayaan hari raya.."

"I (7): kalu nak try tajuk politik malaysia..ok jugak tu ... hahaha ...aaa.. tajuk hari raya ke.."

I (8): tajuk yang ada kena dengan budaya macam..tajuk makanan malaysia la..macam tu la..."

\section{Kesimpulan}

Kajian ini menggunakan kaedah kualitatif dan kaedah pemerhatian, ia bertujuan untuk mengetahui ciriciri tajuk komunikatif yang sesuai untuk dimuatkan dalam buku teks komunikasi Bahasa Arab. Seterusnya untuk mengenal pasti kesesuaian tajuk dalam buku teks Bahasa Arab Komunikasi berdasarkan pendekatan komunikatif. Dapatan kajian daripada temu bual pakar telah menzahirkan beberapa tema penting dalam kajian ini. Berdasarkan penelitian ke atas data-data yang dikumpulkan, maka lahirlah tema-tema berikut sekali gus menjawab ciri-ciri dan tajuk-tajuk komunikatif yang sesuai diterapkan dalam pembangunan kurikulum dan bahan pengajaran bahasa Arab:

Tema 1 : Aktiviti seharian pelajar yang selari dengan konteks mereka sesuai dijadikan tajuk komunikatif. Antara contoh-contoh aktiviti yang dicadangkan ialah aktiviti pelancongan, perkelahan, bersukan, memasak, pengembaraan, membeli belah, ibadah, percutian, membaca, hobi, permainan, belajar dan menonton tv.

Tema 2 : Aspek lokasi dan tempat boleh dijadikan sebagai tajuk komunikatif. Tajuk yang dicadangkan ialah di pejabat, di lapangan terbang, di balai polis, di kaunter, di klinik, di hospital, di pasar raya, di bank, di restoran, di hotel, di universiti, di kedai, di stesen dan di pasar.

Tema 3: Perbualan mengenai aspek geografi, adalah penting. Antara tajuk yang dicadangkan ialah seperti cuaca, masa, tumbuh-tumbuhan, pemandangan kampung, bukit bukau dan seumpamanya, semua aspek tersebut boleh dijadikan sebagai tajuk komunikatif.

Tema 4 : Aspek konteks sosial pelajar sesuai dijadikan tajuk komunikatif seperti konteks pekerjaan, akhlaq Islam, kekeluargaan, kehidupan seharian seperti politik, media sosial seperti internet serta isuisu yang berkaitan dengan sosial budaya dalam masyarakat.

Tema 5 : Tajuk budaya yang sesuai untuk buku teks ialah budaya yang berkisar tentang kehidupan sosial dalam masyarakat Malaysia dan Arab seperti makanan, permainan, pakaian dan perkahwinan. Dapatan temu bual menunjukkan antara tajuk dan bidang komunikasi yang sesuai dengan konteks budaya pelajar ialah budaya makanan Arab dan Malaysia, budaya perkahwinan Arab dan Malaysia, budaya adat resam, permainan rakyat atau permainan tradisional dan budaya kekeluargaan.

Merujuk kepada tema yang terhasil, tajuk-tajuk di dalam buku teks Bahasa Arab Komunikasi sewajarnya di ambil daripada aktiviti seharian pelajar dan lokasi-lokasi yang sering dikunjungi oleh pelajar. Ia juga boleh diambil dari aspek sosial pelajar dan aspek budaya yang berkisar dengan kehidupan mereka seharian untuk dijadikan sebagai tajuk komunikatif. Dapatan tema-tema tersebut, mengukuhkan lagi idea yang dikemukakan oleh Hymes (1972) dalam pendekatan komunikatif, dengan memfokuskan idea tersebut kepada penggunaan bahasa dalam keadaan yang sebenar iaitu mewujudkan 
suasana interaksi sosial di dalam kelas. Maka, dapatan tema-tema dalam kajian ini telah memberi panduan yang lebih terperinci tentang tajuk-tajuk yang sesuai dimuatkan dalam buku teks Bahasa Arab Komunikasi. Selain itu, dapatan kajian ini juga mengukuhkan dapatan kajian Mohd Zuhir (2014) bahawa pengaruh konteks sosio-budaya tempatan dalam teks pembelajaran Arab dapat memberi minat kepada pelajar untuk belajar bahasa.

\section{Rujukan}

Abdullah Hassan. (1986a). Penerbitan Kata dalam Bahasa Melayu. Kuala Lumpur: Penerbit Fajar Bakti.

Abdullah Hassan. (1986b). Isu-Isu Pengintelektulan Bahasa Melayu. Kuala Lumpur: Dewan Bahasa dan Pustaka.

Abdullah Hassan. (1989). Isu-isu Perancangan Bahasa: Pengintelektualan Bahasa Malaysia. Kuala Lumpur: Dewan Bahasa dan Pustaka.

Ab Halim Mohamad. (2008). Kepelbagaian Laras Bahasa Melayu. Kuala Lumpur: Akademi Pengajian Melayu, Universiti Malaya.

Abd. Razak Abdul Karim. (2013). Analisis Laras Resepi Melayu: Satu Analisis Laras Bahasa Melayu Lama. Jurnal Dewan Bahasa, 38(5), 2-9.

Al Muslim Mustapa \& Zamri Arifin. (2015). Penentuan Dimensi Kualiti Guru Bahasa Arab di Malaysia. ISLAMIYYAT, 37(1): 49 - 57.

Al-‘Arabiyy, Salah Abdul Majīd. (1981). Ta'allum al-Lughāt al-Hayyat wa Ta'līmuhā bayn alNazariyyat wa al-Tatbiq. Lubnan: Maktabah Lubnān.

Arnida A.Bakar dan Lubna Abd Rahman. (2021) "Penterjemahan Makna Unsur Budaya dalam Novel Arab 'Saacah Baghdad: Riwayah' ke dalam Bahasa Inggeris melalui Aplikasi e-Translasi Google", Malaysian Journal of Social Sciences and Humanities (MJSSH), 6(3), 69 - 79. doi: https://doi.org/10.47405/mjssh.v6i3.685.

Asmah Omar. (1988). Bahasa Laporan. Kuala Lumpur: Dewan Bahasa dan Pustaka.

Asmah Omar. (1991). Kemahiran Berbahasa. Kuala Lumpur: Pustaka Antara.

Asmah Omar. (2008a). Nahu Kemas Kini Panduan Bahasa Yang Betul. Kuala Lumpur: PTS Publishing Sdn Bhd.

Asmah Omar. (2008b). Wacana Perbincangan, Perbahasan dan Perundingan. Kuala Lumpur: Dewan Bahasa dan Pustaka.

Bogdan, R. C., \& Biklen, S. K. (2003). Qualitative Research of Education: An Introductive to Theories and Methods ( $4^{\text {th }}$ Edition). Boston: Allyn \& Bacon.

Brian, S. (1982). A Handbook of English Language Teaching Terms and Practice. New York: Macmillan.

al-Fawzān, Abdel Rahmān ibn Ibrāhīm., (2008). Durūs al-Dawrāh al-Tadrībiyyah li al-Mu'allimiyy al-Lughati al-'Arabiyyatt li ghayr al-Nātiqīn bihā. Al-Jānib al-Nazariyy. Saudi Arabia: al'Arabiyyatt li al- jamī'.

Fraenkel, J.R. \& Wallen, N.E. (2008). How To Design and Evaluate Research in Education. NewYork: McGraw-Hill.

Halliday, M. A. K. (1973). Explorations in The Functions of Language. London: Edward Arnold.

Hymes, D. (1971). On Communicative Competence. Pride, J.B. dan Janet Holmes (pynt.). Sociolinguistics. Middlesex: Penguin Books.

Hymes, D. (1972). Models of The Interaction of Language and Social Life. Journal of Social Issues, 23(2), 8-38.

Hudson, R.A. (1980). Language Arts \& Disciplines. Publisher: Cambridge University Press.

Ibrahim Abdullah. (2003). Penyediaan Buku Teks Bahasa Arab untuk Pelajar Dewasa. Tesis Sarjana. Kuala Lumpur: Universiti Malaya.

Ibrahim Abdullah. (2019). Penggunaan Laras Bahasa dalam Buku Teks Bahasa Arab Komunikasi Universiti Teknologi MARA Berdasarkan Pendekatan Komunikatif. Tesis Doktor Falsafah. Serdang: Universiti Putra Malaysia.

Kamaruddin Husin. (1995). Laras Bahasa. Kuala Lumpur: Percetakan Utusan Publication \& Distrubutors Sdn. Bhd. 
Kamaruddin Husin. (1999). Pengajaran Lisan: Kemahiran Mendengar dan Bertutur. Kuala Lumpur: Kumpulan Budiman.

Lily Hanefarezan Asbulah. (2021). Tahap Pengetahuan Kolokasi Bahasa Arab dalam kalangan Pelajar Universiti Awam Malaysia. Malaysian Journal of Social Sciences and Humanities (MJSSH), 6(7), 127 - 138. https://doi.org/https://doi.org/10.47405/mjssh.v6i7.888

Littlewood, W.T. (1981). Communicative Language Teaching. Cambridge: Cambridge University Press.

Mansoer Pateda. (1991). Linguistik Terapan. Kuala Lumpur: Penerbit Nusa Indah.

Mansoer Pateda. (2001). Semantik Leksikal. Muat turun pada 29 Jun 2018 daripada: https://catalogue.nla.gov.au/Record/2558905

Mohd Zuhir Abd Rahman. (2005). Penilaian dalam Pembelajaran: Satu Kajian Buku Teks KBSM Bahasa Arab Komunikasi. Tesis Sarjana. Kuala Lumpur: Universiti Malaya.

Mohd Zuhir Abd Rahman. (2014). Pengaruh Konteks Sosiobudaya Tempatan dalam Teks Pembelajaran Arab. Tesis Doktor Falsafah. Serdang: Universiti Putra Malaysia.

Nik Safiah Karim. (2008). Sosiolinguistik Bahasa Melayu dan Pengajaran. Kuala Lumpur: Fajar Bakti.

Hur Hakimah Md. Sallehuddin. (2015). Ekonomi Bahasa Arab dalam Majalah Aswāq. Tesis Sarjana. Kuala Lumpur: Universiti Malaya.

Nurulasyikin Muda dan Hazmi Dahlan. (2020). Perbandingan Dialek Jordan dengan Bahasa Arab Standard. Malaysian Journal of Social Sciences and Humanities (MJSSH), 5(9), 163 - 174. https://doi.org/https://doi.org/10.47405/mjssh.v5i9.488

Patton, M. Q. (2002). Qualitative Evaluation and Research Methods. Ed ke-3. California: Sage Publication.

Rivers, W. M. \& Temperley, M. S. (1978). A Practical Guide to The Teaching of English as A Second or Foreign Language. London: Oxford University Press.

Rogers, E. M. \& Kincaid, D. L. (1981). Communication Network: Toward a New Paradigm for Research. New York: Free Press.

Salahuddin Mohd. Shamsuddin \& Siti Sara Ahmad. (2017). Authenticity of Classical Arabic and Its Relation to Aristotelian Logic (In The Opinions of Some Orientalists and Arab Scholars). World Journal of Education, 7(4), 122-131.

Tu'aymah, Rushdī Ahmed. (2004). Al-Usus al-'Ammat li Manāhij Ta'līm al-Lughat al-'Arabiyyat. Kaherah. Dār al-Fikr al-'Arabiyy.

Ure \& Ellis. (1977). Laras Bahasa. Muat turun pada 29 Jun 2021 dari: http://gurubahasamelayu.blogspot.com/2009/07/laras-bahasa-melayu.html 